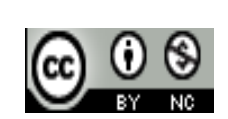

Jurnal Pendidikan Bahasa dan Sastra Indonesia is licensed under

A Creative Commons Attribution-Non Commercial 4.0 International License

\title{
Representasi Perempuan Bali dalam Novel-Novel Karya Oka Rusmini
}

\author{
Sugiyanti Pratiwi Sari ${ }^{1)}$, Agus Nuryatin ${ }^{2)}$, \\ 1. Pendidikan Bahasa Indonesia, Program Pascasarjana, Universitas Negeri Semarang, \\ E-mail: sugiyantips@gmail.com \\ 2. Universitas Negeri Semarang, Indonesia \\ E-mail: anuryatin@yahoo.co.id
}

\begin{abstract}
Abstrak. Representasi perempuan Bali dalam novel-novel karya Oka Rusmini menjadi sebuah kajian menarik dalam sebuah telaah novel, dalam penelitian ini dikaji gambaran perempuan Bali melalui watak tokoh utama perempuan Bali dalam novelnovel karya Oka Rusmini. Sumber data dalam penelitian ini adalah tiga buah novel karya Oka Rusmini, yaitu novel Kenanga, novel Tarian Bumi, dan novel Tempurung. Penelitian ini merupakan penelitian deskriptif kualitatif dengan pendekatan pendekatan strukturalisme dan sosiologi sastra. Hasil dari penelitian ini adalah tokoh utama perempuan dalam novel-novel karya Oka Rusmini digambarkan sebagai perempuan berwatak 1) berani, 2) sarkastis, 3) apatis, dan 4) sabar.
\end{abstract}

Kata kunci : Representasi, perempuan Bali, Oka Rusmini

\section{PENDAHULUAN}

Karya sastra sebagai hasil cipta manusia selain memberikan hiburan juga sarat dengan nilai, baik nilai keindahan maupun nilai-nilai ajaran hidup. Orang dapat mengetahui nilai-nilai hidup, susunan adat istiadat, suatu keyakinan, dan pandangan hidup orang lain atau masyarakat melalui karya sastra. Karya sastra sebagai sebuah kreativitas baik estetis maupun respons terhadap kehidupan sosial, mencoba mengungkapkan perilaku manusia dalam suatu komunitas sosial. Dimensi-dimensi yang dilukiskan merupakan dimensi kehidupan dari sebuah struktur sosial. Dimensi dari struktur sosial yang dimaksud tentu saja struktur sosial masyarakat di mana pengarang memperoleh inspirasinya.

Karya sastra sebagai potret kehidupan bermasyarakat merupakan suatu karya sastra yang dapat dinikmati, dipahami, dan dapat dimanfaatkan oleh masyarakat. Karya sastra tercipta karena adanya pengalaman batin pengarang berupa peristiwa atau problem dunia yang menarik sehingga muncul gagasan imajinasi yang dituangkan dalam bentuk tulisan dan karya sastra akan menyumbangkan tata nilai figur dan tatanan tuntutan masyarakat, hal ini merupakan ikatan timbal balik antara karya sastra dengan masyarakat, walaupun karya sastra tersebut berupa fiksi, namun pada kenyataannya, sastra juga mampu memberikan manfaat yang berupa nilai-nilai moral bagi pembacanya. Sastra selalu menampilkan gambaran hidup dan kehidupan itu sendiri, yang merupakan kenyataan sosial. Dalam hal ini, kehidupan tersebut akan mencakup hubungan antar masyarakat dengan orang seorang, antarmanusia, manusia dengan Tuhannya, dan antar peristiwa yang terjadi dalam batin seseorang.

Semi (1988:8) mengungkapkan bahwa karya sastra adalah suatu bentuk dan hasil pekerjaan seni kreatif yang objeknya adalah manusia dan kehidupannya yang menggunakan bahasa sebagai perantaranya. Karya sastra sebagai struktur bermakna yang mewakili pandangan dunia penulis, bukan sebagai individu, melainkan sebagai wakil golongan. masyarakatnya. Penulis memiliki peran yang sangat penting dalam mengangkat realita-realita sosial yang luput dari pengamatan orang kebanyakan. Karya sastra dapat menjadi sebuah ensiklopedi sosial mini yang memberikan banyak informasi bagi pembaca tentang sebuah struktur dan kehidupan sosial masyarakat tertentu.

Sebuah karya sastra tercipta karena peristiwa atau persoalan dunia yang terekam oleh jiwa pengarang. Peristiwa atau persoalan itu sangat mempengaruhi kejiwaan. Adanya hal demikian, seorang pengarang dalam karyanya menggambarkan fenomena kehidupan yang ada sehingga muncul konflik atau ketegangan batin. Sastrawan, sastra, dan kehidupan sosial merupakan fenomena yang saling melengkapi dalam kedirian masing- masing sebagai sesuatu 
yang ektensial. Sebuah karya sastra tidak dapat dilepaskan dari pengarang dan kehidupan manusia sebagai produk kelahiran karya sastra, sastra bukan sekedar dari kekosongan sosial melainkan hasil racikan perenungan dan pengalaman sastrawan dalam menghadapi problema dan nilai-nilai tentang hidup dan kehidupan (manusia dan kehidupan) pengalaman ini merupakan jawaban yang utuh dari jiwa manusia ketika kesadarannya bersentuhan dengan kenyataan.

Karya-karya fiksi yang merupakan sebuah hasil imajinasi sastrawan tentang komunitas sosial tentu saja bukan semata-mata hasil dari dunia penciptaan yang bersifat khayalan semata, melainkan sebuah karya fiksi lebih dari itu. Hal itu terjadi karena setiap fenomena sosial yang terjadi di masyarakat merupakan indikator dan menjadi objek penciptaan karya sastra. Realitas sosial dalam hal ini merupakan bahan dasar yang kemudian diolah sedemikian rupa dengan kombinasi imajinasi dan intelektualitas pengarang sehingga menjadi sebuah karya. Karya yang dihasilkan tidak hanya bersifat menghibur, tetapi sekaligus juga mendidik. Ratna (2006:389) mengungkapkan bahwa sastra warna lokal memerlukan data khusus dalam bentuk fakta-fakta sosial sesuai dengan semesta yang diacu.

Novel adalah salah satu bentuk karya fiksi yang menyampaikan permasalahan kehidupan yang kompleks. Seorang pengarang mampu mengarang sebuah karya sastra fiksi termasuk novel dengan baik dan biasanya tema yang diangkat diambil dari kehidupan yang pernah pengarang alami sendiri, pengalaman orang lain yang pengarang lihat dan dengar, ataupun hasil imajinasi pengarang. Rekonstruksi terhadap realitas sosial masyarakat Bali menjadi perhatian bagi banyak sastrawan, baik dari Bali sendiri maupun di luar Bali. Hal itu terjadi karena banyak hal yang bisa dibicarakan dari Bali, mulai dari tradisi dan adat. Anwar (2007) dalam artikelnya menyatakan "sebagai kultur, Bali memang khas dan kompleks dibandingkan dengan kultur (etnik) lain di negeri ini. Itulah yang menyebabkan karya-karya sastrawan tentang Pulau Dewata menarik untuk dibicarakan".

Oka Rusmini adalah seorang perempuan Bali yang turut meramaikan kesusastraan Indonesia. Oka Rusmini lahir di Jakarta dan saat ini tinggal di Bali merupakan seorang penulis puisi, novel, dan juga cerita pendek. Karya-karya yang dihasilkan Oka Rusmini bercerita tentang kisah-kisah yang berlatar pulau Dewata dan hampir semua karyanya menggambarkan kehidupan perempuan. Perempuan, budaya, dan pulau dewata menjadi ciri khas dari karya-karya oka Rusmini. Karya-karya Oka Rusmini begitu keras melawan tabu tradisi Bali yang seringkali menimbulkan kontroversi. Oka Rusmini tidak segan membicarakan persoalan adat dan tradisi yang menonjolkan kaum perempuan.

Karya-karya yang pernah ditulis Oka Rusmini diantaranya berjudul Monolog Pohon (1997), Tarian Bumi (2000), Sagra (2001), Kenanga (2003), Patiwangi (2003), Warna Kita (2007), Erdentanz (novel Tarian Bumi edisi bahasa Jerman, 2007), Pandora (2008), Tempurung (2010), Earth Dance (novel Tarian Bumi edisi bahasa Inggris, 2011).

Tiga novel Oka Rusmini berjudul Tarian Bumi, Kenanga, dan Tempurung dipilih sebagai objek dalam penelitian ini. Ketiga novel tersebut menarik untuk dikaji secara bersamaan karena adanya kecenderungan tematis. Oka Rusmini selalu menonjolkan tokoh utama perempuan. Selain sebagai tokoh utama, perempuan sebagai tokoh sampingan dalam novelnya juga memiliki kekhasan. Latar belakang sosiokultural masyarakat Bali tidak pernah lepas dari karya-karya Oka Rusmini. Kendati secara tematis ketiga novel tersebut menceritakan hal yang berbeda, namun jika digeneralisasikan ketiganya sarat akan nilai-nilai sosial dan budaya masyarakat Bali. Salah satu yang selalu dihadirkan Oka Rusmini dalam novelnya adalah mengenai sistem kasta yang ada di Bali. Maka ketiga novel karya Oka Rusmini yaitu Tarian Bumi, Kenanga, dan Tempurung merupakan sebuah karya sastra yang tidak hanya cukup untuk dinikmati saja melainkan perlu mendapat tanggapan ilmiah. Peneliti merasa tertarik untuk mengkajinya dengan pendekatan sosiologi sastra.

\section{METODE}

Pendekatan dalam penelitian ini adalah pendekatan strukturalisme dan sosiologi sastra. Pendekatan strukturalisme digunakan untuk menganalisis watak tokoh utama perempuan dalam novel-novel karya Oka Rusmini dalam menghadapi permasalahan sosial. Fokus penelitian ini adalah mengkaji watak tokoh utama perempuan Bali dalam novel-novel karya Oka Rusmini. Sumber data dalam penelitian ini ada dua, yaitu: (1) tiga buah novel karya Oka Rusmini berjudul Kenanga (2003) Tarian Bumi (2007), dan Tempurung; (2010) yang diterbitkan oleh Gramedia; (2) dokumen atau arsip lain yang mendukung. Data yang digunakan dalam penelitian ini diperoleh melalui studi kepustakaan. Kepustakaan adalah sumber data yang diperoleh dari dokumen dengan mencari data-data mengenai hal-hal atau variabel yang merupakan catatan, transkip, buku, majalah dan lain-lain yang menunjang penelitian.

Sumber data primer dalam penelitian ini berupa kata, frasa, maupun kalimat yang merupakan bagian dari teks cerita. Data primer penelitian ini adalah teks dalam novel-novel karya Oka Rusmini yang merepresentasikan perempuan Bali. Sedangkan sumber data sekunder diperoleh melalui dokumen atau arsip bersumber dari buku, jurnal, internet atau media lain yang mendukung.

Instrumen penelitian digunakan sebagai alat untuk mengumpulkan data yang bersumber pada tiga novel karya Oka Rusmini yaitu novel Kenanga, Tarian Bumi, dan Tempurung. Kegiatan pengumpulan data merupakan bagian yang penting dalam proses penelitian. Pada proses pengumpulan data, dibutuhkan instrumen penelitian atau alat yang digunakan untuk mnegumpulkan data. Pada penelitian ini, yang merupakan penelitian sastra, memiliki dua instrumen penelitian, yaitu: (1) peneliti sebagai instrumen penelitian dan (2) instrumen berupa kartu data.

Teknik pengumpulan data menggunakan teknik membaca heuristic. Menurut Riffaterre (dalam Wellek dan Warren 1990: 148) analisis secara heuristik adalah analisis pemberian makna berdasarkan struktur bahasa secara konvensional, artinya bahasa dianalisis dalam pengertian yang sesungguhnya dari maksud bahasa. Kerja heuristik 
menghasilkan pemahaman makna secara harfiah, makna tersurat, actual meaning (Nurgiyantoro 2007: 33).

Validitas atau keabsahan merupakan kebenaran data dari penelitian. Keabsahan data diperiksa atau diuji dengan cara: 1) membaca berkali-kali data penelitian, 2) membaca dan menelaah berbagai pustaka dan dokumen untuk memperoleh kecukupan rujukan, 3) mengamati secara cermat, terperinci dan teliti sebagai bentuk ketekunan pengamatan, dan 4) mengecek kepada teman sejawat atau informan yang berkeahlian di bidang yang sesuai dengan penelitian.

Teknik analisis data yang digunakan dalam penelitian ini adalah teknik intertekstual. Secara khusus dapat dikatakan bahwa kajian intertekstual berusaha menemukan aspek-aspek tertentu yang telah ada pada karya-karya sebelumnya pada karya yang muncul lebih kemudian. Tujuan kajian intertekstual adalah untuk memberikan makna secara lebih mendalam terhadap karya tersebut. Penulisan dan atau pemunculan sebuah karya sering ada kaitannya dengan unsur kesejarahannya sehingga pemberian makna itu akan lebih lengkap jika dikaitkan dengan unsur kesejarahan itu (Teeuw 1984:62).

\section{HASIL DAN PEMBAHASAN}

Perempuan Bali dalam novel Kenanga digambarkan melalui tokoh utama perempuan yang berwatak 1) idealis dan berambisi, 2) keras kepala, 3) penyayang, 4) berani, 5) sabar, 6) santun, 7) rendah hati, 8) sarkastis, dan 9) apatis. Dalam novel Tempurung, perempuan Bali digambarkan melalui tokoh utama perempuan yang berwatak 1) berani ,2) sarkastis, 3) apatis, 4) penyayang, 5) lapang dada, 6) santun, 7) cerdik, dan 8) bertanggung jawab. Sedangkan dalan novel Tempurung, perempuan Bali digambarkan sebagai sosok berwatak 1) berani, 2) sarkastis, 3) apatis, 4) rendah hati, 5) ambisuis, idealis, 6) keras, 7) berpikiran posistif, 8) jujur, 9) sabar, 10) penyayang.

Berdasarkan data tersebut, perempuan Bali dalam ketiga novel karya Oka Rusmini yaitu novel Kenanga, Tarian Bumi, dan Tempurung digambarkan sebagai perempuan berwatak 1) berani, 2) sarkastis, 3) apatis, dan 4) sabar.

Berani

Sosok Kenanga dalam novel Kenanga, Telaga dalam novel Tarian Bumi, Dayu dan Sipleg dalam novel Tempurung digambarkan sama-sama memiliki watak yang berani. Keberanian tersebut tumbuh kuat dalam diri tokoh karena latar belakang kehidupan dan permasalahan dari masing-masing tokoh.

1) “Anak kita? Bhuana, dimana otakmu? Kau lelaki, bisa bicara apa saja semamumu. Menanggung anak ini, membiayainya. Enak saja. Kaupikir aku tidak sanggup? Persoalannya tidak sesederhana itu. Mungkin bagimu itu soal mudah, buatku berat! Tubuh laki-laki bisa bebas membuang benihnya kemanapun, tapi perempuan? Benih itu tumbuh dalam tubuhku. Nyawaku menjadi taruhannya. Aku bisa mati saat membunuh atau melahirkan janin ini. Tapi risikonya jelas jauh lebih besar kalau janin ini kupertahankan. Bukan hanya untukku, tapi juga untuk anakku. Untuk masa depan kami! (Kenanga:55).

Terlihat bahwa Kenanga adalah perempuan yang berani dan sangat lugas dalam menyampaikan hal yang ada dipikirannya. Kenanga begitu berani dalam menyampaikan gagasannya pada siapapun, termasuk Bhuana. Selain itu, keberanian Kenanga juga digambarkan melalui sikap beraninya mengambil suatu keputusan dan mempertanggungjawabkan keputusan yang diambilnya.

2) "Tuniang! Tuniang bicara apa? Tunianglah yang harus banyak belajar! Jangan membawa kehidupan masa lalu Tuniang untuk masa depan tiang. Apa selama ini Tuniang sudah merasa lebih suci dari ibu?!” Telaga mendelik. Ditatapnya perempuan tua itu tajam. (Tarian Bumi:74).

Telaga merasa hidupnya terlalu banyak diatur dan dicampuri oleh dua orang perempuan di rumahnya yaitu nenek dan ibunya. Telaga merasa tidak suka dengan sikap neneknya yang seringkali menjelekkan ibunya di depan Telaga. Oleh karena itu, Telaga dengan berani menegur sikap neneknya tersebut.

3) Kadang aku berpikir, perempuan tak hanya perlu genit, kadang harus sedikit seronok, sedikit nakal dan berani. Bukankah tubuh mereka adalah rajutan keindahan sejati. Apalagi kalau otaknya berisi. Sempurnalah dosa Pandora tertanam di dalamnya. (Tempurung:3-4).

Kutipan tersebut menunjukkan bahwa sebagai seorang perempuan, Dayu adalah sosok yang berani dan penuh percaya diri. Dia menganggap bahwa perempuan adalah makhluk yang luar biasa. Segala keindahan telah diberikan Tuhan dan dijelmakan dalam tubuh perempuan. Apalagi jika perempuan tersebut memiliki otak yang berisi.

\section{Sarkastis}

Perempuan Bali digambarkan sebagai perempuan yang sarkastis dalam berbicara. Mereka lugas mengungkapkan segala hal yang ada dalam pikiran mereka secara apa adanya.

1) Keringat dingin berkecambah di kening Kenanga. Dia tahu, bila aib ini pecah, orang-orang pasti akan bersorak-sorai memojokkannya. Menjadikannya bulan-bulanan kesalahan dan kenajisan.... Dia terlalu mandiri sebagai seorang perempuan. Kepercayaan dirinya terlampau besar, hingga sering menakutkan. Bagaimana jika ia kedapatan punya anak di luar nikah, tanpa upacara megah yang penuh basa-basi itu? Bagaimana jika ayah anak itu ketahuan? Semua orang pasti berebut menguliti batang-tubuhnya yang jadi tampak tak senonoh, seraya meludah beramairamai: dasar perempuan gatal, ipar sendiri di makan juga! Pasangan ideal Bhuana-Kencana akan muncul sebagai korban kebejatan seorang perempuan terkutuk: Kenanga! (Kenanga: 92).

Kenanga mencemooh dirinya sendiri atas peristiwa yang terjadi di kehidupannya dengan membayangkan pikiran orangorang kepada dirinya jika mereka akhirnya mengetahui 
peristiwa yang menimpa hidupnya.Orang-orang pasti akan mencemoohnya. Kenanga perempuan dengan kepercayaan diri yang tinggi, pendidikan dan karier yang gemilang rupanya memiliki seorang anak perempuan di luar pernikahan. Hal yang lebih mengejutkan yaitu ayah dari anak perempuan tersebut, Bhuana. Adik iparnya.

2) Bagi Telaga, dialah lelaki idiot yang harus dipanggil dengan nama yang sangat agung, Aji, Ayah. Menjijikkan sekali! Lelaki yang tidak bisa bersikap! Lelaki yang hanya mengandalkan kelelakiannya. Bagaimana mungkin dia bisa dipercaya? Ketololannyalah yang membuat seorang perempuan kecil bernama Ida Ayu Telaga Pidada menyesal harus memanggil lelaki itu dengan panggilan terhormat. Karena Telaga memiliki ayah seorang Ida Bagus dan ibunya Ida Ayu, kata orang nilai karat kebangsawanannya sangat tinggi. Untuk memanggil laki-laki yang tidak pernah dikenalnya itu Telaga harus menambahkan kata "ratu". (Tarian Bumi:11).

Bagi seorang anak, menyebut ayahnya sebagai seorang yang menjijikkan dan tolol merupakan hal yang tabu. Namun, bagi Telaga ayahnya adalah sosok yang demikian. Telaga merasa bahwa ayahnya sama sekali tidak berguna dalam kehidupannya. Ayahnya hanya mengandalkan kelelakiannya namun tidak bisa melakukan apapun bagi keluarganya. Telaga menjadi sosok yang sarkastis kepada ayahnya. Kesarkastisan tersebut juga dimunculkan Telaga dalam menilai kakeknya, Ida Bagus Tugur.

3) "Gas! Ibu Dayu!"

(Orang-orang masih memanggilku Dayu, singkatan dari Ida Ayu. Nama kebesaran yang harus kupikul karena aku lahir dari keluarga Brahmana. Bapakku lelaki bergelar Ida Bagus mengawini seorang perempuan Ida Ayu. Konon, derajatku sangat tinggi karena aku lahir dari rahim perempuan bergelar Ida Аyu. Jadi karat kebangsawananku sangat tinggi.Saking tingginya itulah yang membuat aku lupa, manusiakah aku? Bisakah orang dinilai dari derajatnya, dari darahnya? Senista itukah manusia menilai manusia? Menjijikkan! Takaran-takaran yang membuat garis kemanusiaan jadi makin runcing. Bahkan menurutku tak terbentuk, bisa jadi juga untuk menutupi ketakutan mereka sendiri dengan kualitas manusianya. Mungkin pikiran itu yang lebih tepat.) (Tempurung:7).

Kutipan di atas menunjukkan bahwa Dayu bukanlah orang yang menjunjung tinggi kebangsawanannya. Dia justru menunjukkan sikap sarkastis melihat orang-orang begitu bangga terlahir sebagai seorang bangsawan bergelar Ida Ayu dan Ida Bagus. Padahal kualitas sebagai seorang manusia tidak bisa hanya dinilai dari sebuah kelahiran.

\section{Apatis}

Perempuan Bali adalah sosok yang apatis. Berbagai permasalahan yang hadir dalam kehidupan mereka membuat mereka merasa tidak penting untuk memerdulikan hal-hal lain yang dirasa tidak penting bagi kehidupan mereka.
1) ...Tapi Kenanga tak peduli. Biarlah orang pusing dengan berbagai spekulasinya masing-masing. Mungkin itu cara mereka membelai rasa penasaran yang selama ini tak terpuaskan. (Kenanga:72).

Kutipan tersebut menunjukkan bahwa Kenanga adalah orang yang tidak memedulikan spekulasi orang lain atas kehidupannya. Kenanga membiarkan orang-orang berspekulasi atas kehidupannya dan memilih untuk fokus pada kehidupannya dan keinginan-keinginannya.

2) "Kalau tiang ingin bahagia harus disiapkan dari sekarang?" Telaga menatap mata ibunya. Jero kenanga mendelik.

"Ya. Untuk masa depan itu, kita harus berhitung mulai hari ini."

"Kalau tahu jadinya akan begini, tiang tidak ingin jadi dewasa."

"Kenapa?"

"Susah. Merepotkan!” (Tarian Bumi:69).

Telaga merasa tidak perlu memikirkan nasihat ibunya untuk mempersiapkan masa depannya agar kelak dia hidup bahagia. Menurut Telaga hal tersebut adalah hal yang merepotkan.

3) Aku memang tak pernah mengenal secara detail, sosok perempuan yang kupanggil "mamah" karena dia memilih meminggalkan aku dan seorang adikku, memilih lelaki lain yang dia anggap mampu membahagiakannya. (T:14)

Aku tak pernah lagi bermimpi mendapatkan apa pun darinya. Percuma. Sebuah peristiwa yang membuatku makin tidak simpatik padanya kelaka kan kuceritakan padamu. Sekarang kau bisa lihat, bagaimana ibu-ibu seusia ibuku berlagak seperti $\mathrm{Bu}$ Barla. (Tempurung:15).

Kutipan di atas menunjukkan bahwa Dayu merasa apatis kepada sosok ibunya karena ibunya telah meninggalkannya beserta adiknya untuk hidup dengan lakilaki lain. Dayu tidak lagi mengharapkan apapun dari ibunya dan tidak lagi memiliki perasaan simpatik pada perempuan yang telah melahirkannya itu.

\section{Sabar}

Perempuan Bali digambarkan sebagai sosok yang sabar dalam menjalani segala permasalahan dalam kehidupannya, termasuk segala risiko-risiko yang datang sebagai konsekuensi dari pilihan-pilihan yang diambilnya.

1) Kenanga melotot. Kali ini dia benar-benar tidak mengerti. Di helanya napas dalam-dalam. Apa maunya anak kesayangan ibu ini? Apakah aku akan kembali menjadi korbannya? Pikir Kenanga. Kenangan kanak-kanak yang kembali berloncatan dari otaknya, memulai adegan yang telah berulang dipentaskan di depan matanya. Adegan-adegan yang begitu dihafalnya. Tak ada detail secuil pun yang tertinggal.

Liang luka masa silam Kenanga kembali basah. Segurat jejak telah tertoreh dalam tulang- 
belulangnya, tembus ke sumsum, menusuk jantung dan jiwanya.

Kenanga sadar, dari dulu dia tidak pernah menang bila bertengkar dengan Kencana....

Berdasarkan kutipan di atas, diketahui bahwa Kenanga memiliki masa lalu yang kurang membahagiakan. Kenanga memiliki masa kecil yang kurang menyenangkan karena merasa segala kasih sayang kedua orang tuanya hanya tercurah untuk Kencana, adiknya. Kenanga merasa orang tuanya tidak adil dalam membagi kasih sayangnya pada dirinya dan Kencana, namun Kenanga masih bisa berlapang dada hingga akhirnya dia tumbuh dewasa.

2) Telaga merasa orang-orang selalu lebih tahu daripada dirinya sendiri. Padahal, mereka sama sekali tidak tahu seperti apa perasaan Telaga ketika kawin dan hidup sebagai perempuan Sudra untuk pertama kalinya. Wayan hanya bisa membelikan kebaya dan kain yang kasar. Telaga benar-benar melatih diri untuk menanggalkan seluruh busana kebangsawanannya. Semua untuk cinta. Untuk perhatian, untuk kasih sayang yang tidak pernah dia dapatkan dari laki-laki. (Tarian Bumi:149).

Kutipan di atas menunjukkan bahwa kehidupan Telaga setelah menikah dengan Wayan tidaklah mudah. Kehidupan barunya sebagai perempuan sudra sangat berbeda dengan kehidupan Telaga sebelumnya sebagai perempuan brahmana. Hal tersebut diterima Telaga dengan sabar. Telaga mampu melatih diri untuk menanggalkan seluruh busana kebangsawanannya demi cinta, perhatian dan kasih sayang dari seorang lelaki yang belum pernah dia dapatkan.

3) "Sipleg tidak pingsan dan tidak menangis."

"Hus. Pelankan sedikit suaramu."

"Bukankah perempuan itu memang perempuan aneh."

"Memang aneh." (Tempurung:155).

Bagi Sipleg, Pidagda adalah perempuan yang malang. Sipleg merasa sangat menyesali peristiwa yang harus menimpa majikannya, Pidagda. Pidagda meninggal karena dibunuh oleh Sarah, anaknya Maya, cucunya sendiri yang diduga memiliki kelainan mental. Rasa sayang Sipleg kepada Pidagda membuatnya mengumpulkan serpihan tulang Pidagda.

\section{SIMPULAN DAN SARAN}

\section{SIMPULAN}

Berdasarkan berbagai penjabaran di atas dapat disimpulkan bahwa perempuan Bali dalam novel-novel karya Oka Rusmini digambarkan sebagai sosok yang berwatak 1) berani, 2) sarkastis, 3) apatis, dan 4) sabar. Keempat watak tersebut didasari oleh berbagai permasalahan hidup yang dialami oleh masing-masing tokoh.

Saran dalam penelitian ini, yaitu dapat dijadikan panduan dalam mengapresiasi sastra serta panduan dalam mengapresiasi sastra serta mengembangkan pengetahuan dan menambah wawasan tentang penelitian sastra. Selain itu, pembaca diharapkan mengenal teori sastra yang dapat digunakan sebagai alat penelitian sastra.

\section{DAFTAR PUSTAKA}

Anwar, Wan. (2007). "Potret Gelap Keluarga Griya dalam Novel Kenanga Karya Oka Rusmini". Makalah yang disampaikan pada Pelatihan APRESDA Guru Tingkat Nasional.

Nurgiyantoro, Burhan. (2007). Teori Pengkajian Fiksi. Yogyakarta: Gajah Mada.

Rayna, Nyoman Kutha. (2006). Teori, Metode, dan Teknik Penelitian Sastra. Cetakan Kedua.Yogyakarta: Pustaka Pelajar.

Rusmini. Oka. (2003). Kenanga. Jakarta: Grasindo.

Rusmini. Oka. (2007). Tarian Bumi. Jakarta: Gramedia.

Rusmini. Oka. (2010). Tempurung. Jakarta: Gramedia.

Semi, Atar. (1988). Anatomi Sastra. Padang: Angkasa Raya.

Teeuw. (1984). Sastra dan Ilmu Sastra, Pengantar Teori Sastra. Jakarta: PT Dunia Pustaka Jaya

Wellek, Rene \& Austin Warren. (1990). Teori Kesusastraan (Terj. Melani Budianta). Jakarta: PT Gramedia. 